\title{
Barry Hudock
}

Struggle, Condemnation, Vindication:John Courtney Murray's Journey toward Vatican II. Collegeville: Liturgical Press. Pp. 216. Pb, \$19.95.

American Jesuit John Courtney Murray (1904-1967) is well known both for his work as a public philosopher, as exemplified in his celebrated book We Hold These Truths, and as a leading architect of the church's "Declaration on Religious Freedom" (Dignitatis humanae) at Vatican II, which affirmed religious freedom as a fundamental civil right. In Struggle, Condemnation, Vindication: John Courtney Murray's Journey toward Vatican II, Barry Hudock focuses chiefly on Murray's contribution to church teaching on religious liberty.

Concerned that most younger Catholics are unfamiliar with Murray and his achievement, Hudock wants to make Murray's work better known to them and to the larger community. As he indicates in his Introduction, his book is a successor to Donald Pelotte's earlier work John Courtney Murray: Theologian in Conflict (Mahwah: Paulist Press, 1976), which covered much of the same ground. While acknowledging the value of Pelotte's book, Hudock notes that it is out of print, and that in the nearly four decades since its publication important new resources have appeared, including major articles by Joseph Komonchak, and the personal correspondence of Joseph Clifford Fenton, that greatly enrich our understanding of Murray's achievement. In addition, the Pelotte book is scholarly in nature, while Hudock intends to offer something more accessible to the general public, which not only describes what Murray accomplished, but captures the personal drama he experienced.

The result is a lively, fast moving narrative in the form of "a theological adventure story" (as Hudock characterizes it), whose leading characters are Murray and his two principal antagonists, Monsignor Joseph Clifford Fenton, a theologian at Catholic University and editor of the influential American Ecclesiastical Review, and Cardinal Ottaviani, prefect of the Holy Office (now the Congregation for the Doctrine of the Faith). The story is set against the background of the pre-Vatican II church's support for the confessional state and the old thesis/hypothesis framework whereby the Catholic ideal was that in countries like Spain, with a predominantly Catholic population, Catholicism should be the state religion and restrictions should be placed on the freedom of other religions (the thesis), whereas in countries like the United States, where Catholics were in the minority and a Catholic confessional state was not feasible, the right to religious freedom was accepted (the hypothesis).

Hudock explains how Murray, beginning in the 1940s, responded to this situation by adopting an historically-minded approach to the way the relation between church and state is to be understood in the Catholic tradition, seeking 
to separate the permanent or transtemporal elements in that tradition from those that were historically conditioned. Murray argued that with the Gelasian dyarchy (from Gelasius I in 494), Christianity inaugurated a distinction between spiritual and temporal authority that gave rise to a nascent constitutionalism in the Middle Ages, but that with the subsequent emergence of the nation state the Gelasian principle took two divergent paths: in continental Europe, it suffered rejection, first at the hands of royal absolutism and then, following the French Revolution, from a virulently secular, anti-clerical liberalism. It fared much better in the Anglo-American world, particularly the United States, where the Gelasian dyarchy found substantial, if imperfect, expression in the religion clauses of the First Amendment. Murray argued that condemnations of the separation of church and state and of religious freedom by nineteenth-century pontiffs reflected justified opposition to the laicism of continental liberalism, but did not apply to the American version of churchstate separation (with which the popes were not familiar). Murray further contended that the encyclicals of Leo XIII, on which he wrote extensively in Theological Studies, the Jesuit journal he edited, constituted a revival of the Gelasian principle. Furthermore, this principle was further developed by subsequent popes, particularly Pius XII, along lines reflecting support for limited constitutional government and the rights associated with modern democratic states, including the right to religious freedom.

As Hudock recounts in detail, Murray's interpretation of Leo XIII and the contribution of more recent popes met with stiff opposition from Monsignor Fenton and his Catholic University of America colleague Father Francis Connell, who rejected Murray's historically-conscious approach and pointed out numerous papal texts that challenged Murray's claims. Monsignor Fenton also sent a number of private communications to Cardinal Ottaviani, expressing concern about Murray's views and calling for action from Rome against him. After a speech at CUA in 1954 on Pius XII's address to Catholic jurists, $C i$ riesce, in which Murray claimed that the pope had repudiated the thesishypothesis model of church-state relations, as well as also making remarks that were interpreted as critical of Cardinal Ottaviani, such action came. In 1955, Murray was required to cease publishing on church-state issues and his last major article on Leo XIII was withheld from publication.

Hudock then describes in detail Murray's subsequent vindication at Vatican II. Although absent from the first session of the council (from which Murray said he was "disinvited"), Murray was chosen by Cardinal Spellman as a peritus for the second session and played a key role thereafter both as a major contributor to the many drafts of the document that eventually became Dignitatis humanae and as an advisor to the American bishops, whose support for 
Dignitatis humanae in debates on the council floor proved crucial to its approval. Hudock does a good job of capturing the tense and at times dramatic atmosphere in which the supporters, like Murray, of the document endorsing religious freedom and those, like Ottaviani and his allies, who opposed it, clashed. Ultimately, of course, Murray's side triumphed, and he is credited with making a major contribution to the development of doctrine in this area.

This is a valuable book for anyone interested in Murray, but I think it will be especially so to readers new to the man, for whom it will serve as a good introduction. I can see it working well in undergraduate courses, for example. It is not, however, an in-depth study of Murray's life and thought. One hopes that someday someone (Father Komonchak, perhaps) will give us this kind of intellectual biography of Murray.

\section{William Gould}

Fordham University

Wgould@fordham.edu

DOI $10.1163 / 22141332-00204008-19$ 